\title{
Pengaruh Penambahan Probiotik Dengan Dosis Berbeda Pada Pakan Terhadap Pertumbuhan Dan Rasio Konversi Pakan (Fcr) Ikan Nila \\ (Oreochromis Niloticus)
}

\author{
Ahmad Fahrizal ${ }^{1}$, M. Nasir ${ }^{2}$ \\ 1) Staf Pengajar di Fakultas Perikanan Universitas Muhammadiyah Sorong \\ 2) Mahasiswa Fakultas Perikanan Universitas Muhammadiyah Sorong \\ Email: a.fahrizal.ab@gmail.com
}

\begin{abstract}
Abstrak
Penelitian ini bertujuan untuk mengetahui pengaruh penambahan atau aplikasi probiotik menggunakan dosis berbeda pada pakan terhadap pertumbuhan ikan nila.Metode yang digunakan pada penelitian ini yaitu metode eksperimen/percobaan dengan analisa data yang digunakan menggunakan Rancangan Acak Lengkap (RAL). Wadah yang digunakan adalah ember dengan volume 100 liter, 13 buah. Penelitian ini terdiri dari 1 kontrol dan 3 perlakuan dengan ulangan setiap perlakuan sebanyak 4 kali. Ikan uji pada setiap wadah diisi sebanyak 10 ekor. Penggunaan dosis probiotik pada perlakuan I yaitu dosis $5 \mathrm{ml}$, perlakuan II :10 ml, serta perlakuan III yaitu $15 \mathrm{ml}$.Hasil penelitian menunjukkan bahwa nilai konversi pakan atau Food Convertion Ratio (FCR) yang diperoleh pada perlakuan I, II, dan III secara berturut-turut adalah 1.82, 1.75, dan 1.73. Nilai konversi pakan/FCR terbaik yaitu perlakuan III dengan dosis $15 \mathrm{ml}$ diperoleh nilai FCR 1.73. Hal ini bermakna setiap pemberian pakan sebanyak $1,73 \mathrm{~kg}$, akan menghasilkan $1 \mathrm{~kg}$ ikan nila. Sedangkan nilai Survival Rate (SR)yang diperoleh ayitu sebesar $100 \%$ atau ikan nila yang dipelihara pada penelitian ini, tidak mengalami kematian.Kesimpulan dari penelitian ini adalah dengan penambahan probiotik menggunakan dosis berbeda pada pakan ikan nila, tidak berpengaruh signifikan terhadap pertumbuhan bobot dan panjang ikan nila dengan menggunakan analisis sidik ragam (anova). Pemberian probiotik lebih memberikan pengaruh terhadap FCR ikan nila.
\end{abstract}

Kata Kunci : Pengaruh probiotik, pertumbuhan, FCR.

\section{PENDAHULUAN}

(FAO Fisheries and Aquaculture Department,) mengatakan bahwa budidaya Nila tilapia (Oreochromis niloticus) dapat ditelusuri ke zaman Mesir kuno seperti yang digambarkan pada relief dari makam Mesir yang berusia lebih dari 4000 tahun.Ikan Nila berasal dari nila Tilapia Jepang yang diintroduksi masuk ke Thailand, kemudian ke Filipina. Arboleda (1981) dalam International Center for Living
Aquatic Research Management (ICLARM) pada tahun 1987di Filipina mengembangkan jenis nila tilapia ini untuk pertama kalinya. Program tersebut dibiayai oleh Asian Development Bank (ADB) dan United Nations Development Programme (UNDP).

Khairuman, dan Amri, (2005), mengatakan bahwa ikan nila merupakan ikan air tawar populer di masyarakat 
sehingga prospek usaha ikan nila cukup menjanjikan. Ditinjau dari segi pertumbuhan, ikan nila adalah jenis ikan yang memiliki laju pertumbuhan yang cepat dan dapat mencapai bobot tubuh yang jauh besar dengan tingkat produktivitas yang cukup tinggi.Faktor lainnya adalah kekhasan darirasa dagingnya yangberwarna putih bersih, tidak berduri, kaya akan kandungan gizi sehingga dijadikan sumber protein murah, mudah didapat, serta harga jual yang terjangkau masyarakat.Prospek budidaya ikan nila juga diperkirakan memiliki peluang yang sama baiknya untuk dikembangkan selain jenis ikan konsumsi lainnya, karena ikan nila produktif apabila dipelihara di berbagai lahan, bukan hanya di kolam air tawar, tetapi juga dipelihara di tambak-tambak air payau.

Hal yang berpengaruh lainnya adalah karena ikan nila memiliki batasan toleransi yang cukup tinggi terhadap perubahan berbagai kondisi lingkungan perairan. Umumnya, ikan nila ukuran kecil lebih tahan terhadap fluktuasi atau perubahan lingkungandibandingkan dengan ikan nila yang berukuran besar (Khairuman dan Amri, 2005).

Kabupaten Sorong merupakan daerah yang memiliki potensi sumberdaya alam yang melimpah di daratan serta di lautan. Sebagian besar potensi yang ada tersebut belum banyak dioptimalkan dan dikelola secara baik. Salah satu potensi yang dimiliki adalah lokasi budidaya yang masih sangat potensial untuk dikembangkan terutama dalam budidaya ikan nila, seperti kegiatan budidaya ikan nila yang di lakukan oleh beberapa kelompok pembudidaya di Distrik Aimas.

Permasalahan yang dihadapi para pembudidaya ikan nila di Distrik Aimas adalah ketersediaan pakan yang terbatas serta mahalnyaharga pakan. Oleh karena itu, perlu diambil langkah guna menekan biaya pakan yang dapat menunjang efisiensi pakan dengan pola pemberian pakan yang tidak berlebihan, menggunakan pakan tambahan alternatif yang lebih murah serta menerapkan teknologi yang tepat dapat mengurangi kebutuhan pakan ikan. Hal tersebut mendorong penulis memilih judul penelitian tentang: Pengaruh Penambahan Probiotik Dengan Dosis yang Berbeda Pada Pakan Terhadap Pertumbuhan Dan Rasio Konversi Pakan (FCR) Ikan Nila (Oreochromis niloticus).

\section{METODE}

Metode yang diterapkan pada penelitian ini ialah metode eksperimen. Metode eksperimen dilakukan dengan melakukan percobaan serta pengamatan secara langsung dengan membuktikan sesuatu yang diteliti/dipelajari secarasendiri. Selain itu Gay (1981) dalam(Setyanto, 2013)menyatakan bahwa metode penelitian eksperimental adalah satu-satunya metode penelitian yang dapat menguji kebenaran suatu hipotesis yang menyangkut hubungan kausal (sebab-akibat). Pada penelitian eksperimen, manipulasi dilakukan melibatkan 1 atau lebih variabel, mengontrol variabel lainnya yang relevan terhadap penelitian, mengobservasi atau mengamatipengaruh suatu variable terhadap variabel lainnya.

\section{Prosedur Pengumpulan Data}

Prosedur penelitian yang dilakukan pada kegiatan penelitian ini adalah menyiapkan dan membersihkan wadah dan peralatan 1 hari sebelum pelaksanaan penelitian agar terkondisikan steril dari potensi atau munculnya berbagai penyakit. Persiapan biota percobaan yaitu benih ikan nila dengan jumlah 10 ekor benih 


\section{Median Volume IX Nomor 1 Bulan Februari 2017}

dengan ukuran 8-10 $\mathrm{cm}$ pada setiap wadah(ember) serta pakan ikan nila.

Pada pengukuran kualitas air harian dilakukan pengukuranmeliputi $\mathrm{pH}$, DO, dan suhu. Pengukuran dilakukan pada pagi dan sore hari yaitu pada pukul 07.00-07.30 WIT serta pukul 16.00-16.30 WIT. Pengukuran $\mathrm{pH}$ menggunakan $\mathrm{pH}$ meter, pada suhu dilakukan pengukuran dengan menggunakan thermometer suhu, dan pada DO dilakukan dengan pengukuran menggunakan DO meter. Setelah dilakukan pengukuran, dicatat pada tabel data hasil pengamatan.

Sebelum memberikan pakan pada ikan uji, terlebih dahulu dilakukan perhitungan berat ikan secara keseluruhan (biomassa). Penimbangan berat pakan yang dibutuhkan dengan dosis 5\% dari berat tubuh ikan (biomassa). Sedangkan jumlah pemberian probiotik yang digunakan dilakukan dengan dosis yang berbeda. Perlakuan I menggunakan dosis 5ml, perlakuan II dengan dosis $10 \mathrm{ml}$, serta perlakuan III dengan dosis $15 \mathrm{ml}$. Selanjutnya, probiotik dicampurkan pada pakan. Pemberian pakan dilakukan pada pagi dan sore hari yaitu pukul 08.00-08.30 WIT dan pukul 16.3017.00

WIT.

Tabel 1.Komposisi Pakan

\begin{tabular}{|c|c|c|c|c|}
\hline Waktu & Dosis & Frekuensi & $\begin{array}{l}\text { Jenis } \\
\text { Dakan }\end{array}$ & Mutu/komposisi pakan \\
\hline $\begin{array}{ll}\text { - } & \text { Pagi hari } \\
\text { (pukul 08.00- } & \\
08.30 \mathrm{WIT}) \\
\text { - } & \text { Sore hari } \\
& \text { (pukul 16.30- } \\
& \text { 17.00 WIT) }\end{array}$ & $\begin{array}{l}5 \% \text { dari } \\
\text { berat tubuh } \\
\text { ikan }\end{array}$ & $2 \times$ sehari & Pakan buatan & $\begin{array}{l}\text { Protein kasar 35\% } \\
\text { Lemak kasar } 2 \% \\
\text { Serat kasar } 3 \% \\
\text { Abu kasar } 13 \% \\
\text { Kadar air } 12 \%\end{array}$ \\
\hline
\end{tabular}

Sumber : Daftar Label Pakan Merk FF 999

\section{Teknik Analisis Data}

Analisis data yang digunakan yakni Rancangan Acak Lengkap (RAL). Rancangan Acak Lengkap merupakan rancangan yang paling sederhana, cocok untuk materi yang bersifat homogen yang artinya variasi diantaranya relatif kecil. Rancangan Acak Lengkap tidak memiliki lokal control, sehingga cocok digunakan untukkondisi lingkungan yang homogen, termasuk bahan,alat, media meliputi laboratorium, rumah kaca (green house) atau ruang terkontrol lainnya (Hanafiah, 1991) dalam (Mursalim, 2018).

Rancangan Acak Lengkap (RAL) tersebut terdiri atas 3 perlakuan dengan 4 kali ulangan pada setiap perlakuan. Adapun perlakuan tersebut adalah :
- Perlakuan A: Pemeliharaan ikan nila dengan penambahan probiotik 5 $\mathrm{ml}$ dari jumlah pakan yang digunakan.

- Perlakuan B : Pemeliharaan ikan nila dengan penambahan probiotik $10 \mathrm{ml}$ dari jumlah pakan yang digunakan.

- Perlakuan C : Pemeliharaan ikan nila dengan penambahan probiotik $15 \mathrm{ml}$ dari jumlah pakan yang digunakan.

Data yang diperoleh selanjutnya dianalisis sidik ragam atau analysis of variance(ANOVA) untuk mengetahui pengaruh perlakuan yang diberikan terhadap pertumbuhan serta kelangsungan hidup/survival rate (SR) ikan yang di uji. 


\section{Median Volume IX Nomor 1 Bulan Februari 2017}

\section{Perhitungan Pertumbuhan}

\section{- Pertumbuhan Berat Muntlak}

Effendi, (2004) mengatakan bahwa pertumbuhan berat mutlak dihitung menggunakan rumus berikut ini:

$$
\text { Rumus : } W=W t \text { - Wo }
$$

Keterangan Rumus :

W : Pertumbuhan berat muntlak

Wt : Berat akhir ikan $(\mathrm{g})$

Wo: Berat awal ikan (g).

\section{- Laju Pertumbuhan Spesifik}

Laju pertumbuhan spesifik diukur setiap minggu pertama hingga minggu akhir penelitian. Laju pertumbuhan dihitung menggunakan rumus Specific Growth Rate (SGR). Menurut (Huisman, 1976) dengan rumus sebagai berikut :

Rumus : $\quad$ SGR $=\frac{W t-W o}{t} \times 100 \%$

Keterangan Rumus :

SGR : Laju pertumbuhan mingguan (\%)

Wt : Bobot rata-rata ikan pada waktu $\mathbf{t}$ (g)

Wo : Bobot rata-rata ikan pada waktu awal penelitian $(\mathrm{g})$

$\mathrm{t}$ : Waktu penimbangan (hari).

\section{Perhitungan FCR (Feed Convertion Ratio)}

Menurut Djarijah (1995)untuk menghitung efisiensi pakan yang digunakan dapat digunakan rumus di bawah ini:

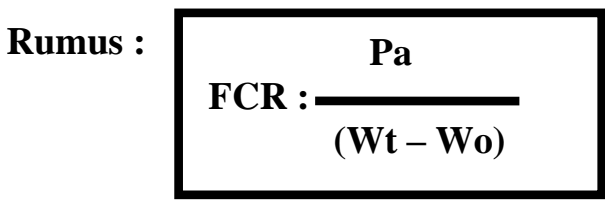

Keterangan Rumus :

FCR : Feed Convertion Ratio

$\mathrm{Pa}$ : Jumlah pakan yang dikonsumsi

Wt : Biomassa ikan akhir $(\mathrm{kg})$

Wo : Biomassa ikan awal (kg)

\section{Tingkat Kelangsungan Hidup/ Survival Rate (SR)}

Untuk mengetahui nilai SR digunakan rumus Baktiar (2006) sebagai berikut:

Rumus : $\mathrm{SR}=\frac{\mathrm{Nt}}{\mathrm{No}} \times 100 \%$

Keterangan Rumus :

SR : Persentase kelangsungan hidup (\%)

$\mathrm{Nt}$ : Jumlah populasi ikan akhir (ekor)

No : Jumlah populasi ikan awal (ekor)

\section{HASIL DAN PEMBAHASAN PENELITIAN}

\section{Gambaran Hasil Pengolahan Data}

Pengukuran pertumbuhan berat dilakukan satu kali seminggu dan selama penelitian pengukuran berat dilakukan sebanyak 5 yaitu pengukuran pada berat awal dan sampai pada minggu ke empat. Hasil pertumbuhan ikan nila (Tabel 2) dianalisis dengan dengan analisis sidik ragam atau anova(Tabel 3).Hasil pengukuran berat dapat dilihat pada Gambar 1.

Tabel 2. Laju Pertumbuhan Ikan Nila

\begin{tabular}{|c|c|c|c|c|c|c|}
\hline \multirow{2}{*}{$\begin{array}{l}\text { Kosentrasi probiotik } \\
(\mathrm{ml})\end{array}$} & \multicolumn{4}{|c|}{ Ulangan } & \multirow{2}{*}{$\begin{array}{l}\text { Jumlah } \\
\text { (gram) }\end{array}$} & \multirow{2}{*}{$\begin{array}{l}\text { Rerata } \\
\text { (gram) }\end{array}$} \\
\hline & 1 (gram) & 2 (gram) & 3 (gram) & 4 (gram) & & \\
\hline $5 \mathrm{ml}$ & 436 & 434 & 435 & 438 & 1.743 & 435.75 \\
\hline $10 \mathrm{ml}$ & 462 & 461 & 462 & 459 & 1.844 & 461 \\
\hline $15 \mathrm{ml}$ & 512 & 508 & 510 & 502 & 2.032 & 508 \\
\hline Jumlah & 1.410 & 1.403 & 1.407 & 1.399 & 5619 & 1.404 .75 \\
\hline
\end{tabular}




\section{Median Volume IX Nomor 1 Bulan Februari 2017}

Tabel 3. Hasil Perhitungan Analysis of variance (anova)

\begin{tabular}{lrrrrrr}
\hline \multicolumn{1}{c}{$\begin{array}{c}\text { Sumber } \\
\text { Variasi }\end{array}$} & \multicolumn{1}{c}{$J K$} & \multicolumn{1}{c}{$d b$} & \multicolumn{1}{c}{ KT } & F Hitung & P-value & F Tabel \\
\hline Antara Kelompok & 32438 & 2 & 16219 & 0.032713682 & 0.96793 & 4.256495 \\
Dalam Kelompok & 4462078 & 9 & 495786.4444 & & & \\
\hline Total & 4494516 & 11 & & & & \\
\hline
\end{tabular}

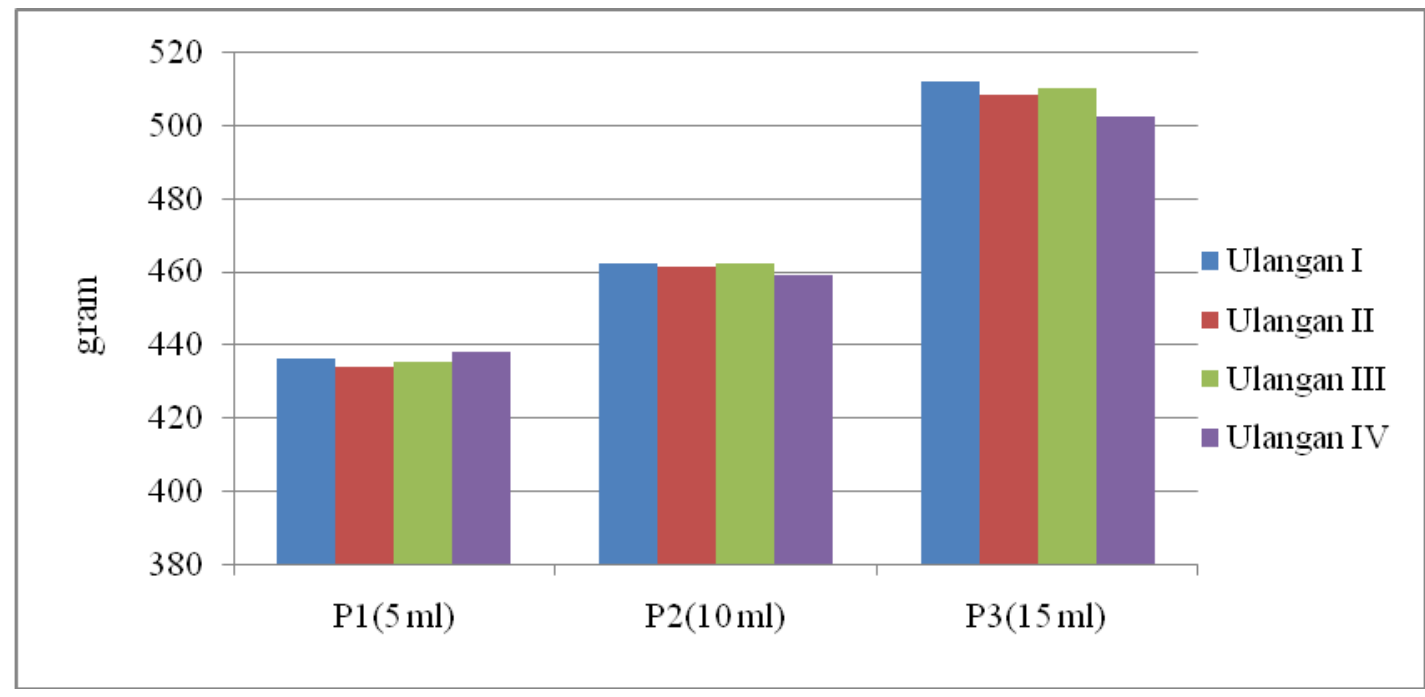

Gambar1. Grafik Pertumbuhan Berat Ikan Nila

\section{Pertumbuhan Panjang}

Selain pengukuran berat ikan nila, pengukuran pertumbuhan panjang pun dilakukan pada penelitian ini dengan metode analisis statistik yang sama yaitu uji sidik ragam (anova). Adapun hasil pengukuran panjang yang diperoleh pada penelitian ini disajikan pada Tabel 4 dan Gambar 2 di bawah ini.

Tabel 4. Laju Pertumbuhan Panjang Ikan Nila

\begin{tabular}{ccccccc}
\hline \multirow{2}{*}{$\begin{array}{c}\text { Kosentrasi probiotik } \\
(\mathrm{ml})\end{array}$} & \multicolumn{5}{c}{ Ulangan } & Jumlah \\
\cline { 2 - 5 }$(\mathrm{cm})$ & $2(\mathrm{~cm})$ & $3(\mathrm{~cm})$ & $4(\mathrm{~cm})$ & $(\mathrm{cm})$ & Rerata $(\mathrm{cm})$ \\
\hline $5 \mathrm{ml}$ & 19.8 & 20 & 19.5 & 19.9 & 79.2 & 19.8 \\
$10 \mathrm{ml}$ & 19.6 & 19.19 & 19.9 & 20 & 78.69 & 19.6725 \\
$15 \mathrm{ml}$ & 20.1 & 19.8 & 20 & 19.8 & 79.7 & 19.925 \\
\hline
\end{tabular}

Tabel 5. Hasil Hitungan Anova

\begin{tabular}{lrrrrrr}
\hline $\begin{array}{c}\text { Sumber } \\
\text { Variasi }\end{array}$ & \multicolumn{1}{c}{$J K$} & \multicolumn{1}{c}{ Db } & \multicolumn{1}{c}{ KT } & F Hitung & P-value & F Tabel \\
\hline Antara Kelompok & 0.2894 & 2 & 0.1447 & 0.000163976 & 0.999836 & 4.256495 \\
Dalam Kelompok & 7942.0076 & 9 & 882.4452889 & & & \\
\hline Total & 7942.297 & 11 & & & & \\
\hline
\end{tabular}




\section{Median Volume IX Nomor 1 Bulan Februari 2017}

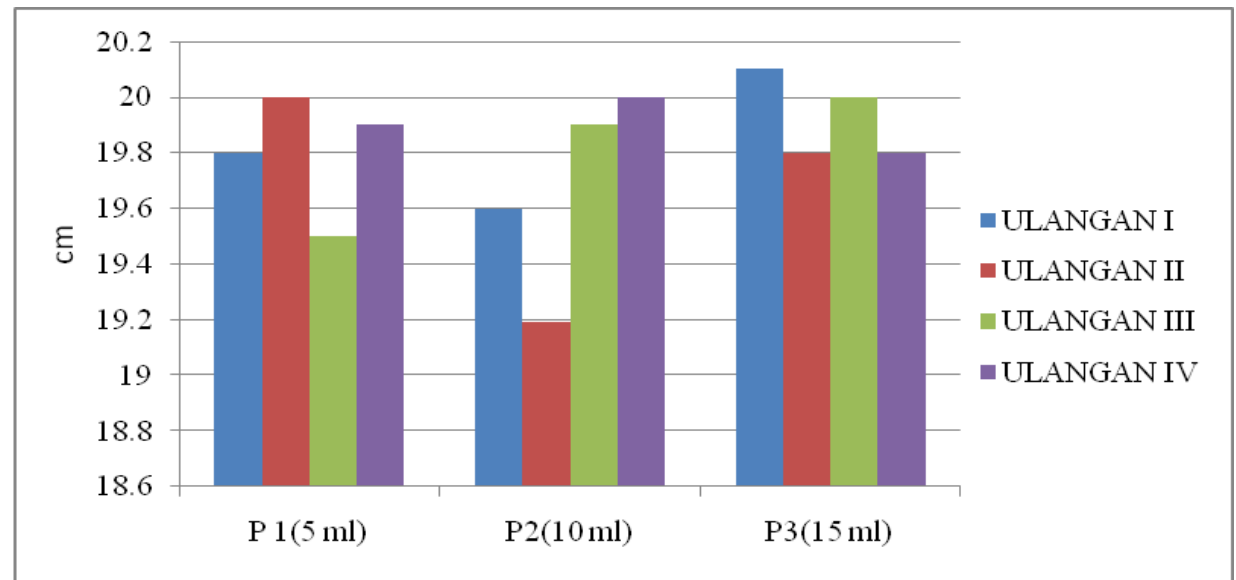

Gambar 2. Grafik Pertumbuhan Panjang Ikan Nila

Gambar 2 di atas dapat dilihat bahwa pemberian probiotik tidak berpengaruh secara signifikan terhadap pertumbuhan berat dan panjang ikan nila yang didasarkan hasil uji sidik ragam anova menunjukkan bahwa secara statistik nilai ketiga perlakuan tidak berbeda secara signifikan dimana nilai $\mathrm{f}$ tabel lebih besar daripada nilai $\mathrm{f}$ hitung yang menandakan bahwa ketiga perlakuan memiliki notasi yang sama. Sehingga tidak perlu melakukan uji statistik atau uji lanjut seperti uji Beda Nyata Terkecil (BNt) karena nilai pada $\mathrm{f}$ Hitung lebih rendah dari f Tabel.Gomes dan Gomes (1984) dalam Hanafiah (1991) bahwa uji BNt akan dilakukan apabila nilai f hitung lebih tinggi dari nilai f Tabel.

\section{Survival Rate (SR) atau Kelangsungan Hidup}

Tingkat kelangsungan hidup atau survival rate (SR) ikan adalah presentase jumlah ikan hidup pada akhir penelitian dibandingkan dengan jumlah ikan pada awal pemeliharaan. Untuk mengetahuinya digunakan yang dikemukakan oleh Baktiar, (2006).

Pada penelitian ini hasil yang diperoleh bahwa tingkat kelangsungan hidup ikan nila adalah $100 \%$ yang artinya bahwa objek penelitian atau ikan nila tidak mengalami kematian. Hasil ini diperoleh tidak terlepas dari persiapan wadah yang baik, penggunaan pakan dengan kandungan gizi baik, serta pengontrolan kualitas air yang teratur.

Untuk mempertahankan kelangsungan hidup serta pertumbuhan ikan, maka diperlukan makanan yang memenuhi nutrisi ikan. Faktor yang mempengaruhi kelangsungan hidup ikan adalah padat tebar, pemberian pakan, penyakit dan kualitas air yang meliputi suhu, kadar amoniak, kadar nitrit, kadar oksigen terlarut, serta $\mathrm{pH}$ perairan. Nilai daya kelangsungan hidup ikan yang baik rata-rata 63,5 - 86,0 (DEPTAN, 1999). Sedangkan menurut Akhmad (2011), bahwa daya kelangsungan hidup ikan sepat rawa berkisar antara 68,89-75,56\%.

\section{Rasio Konversi Pakan atau Feed Conversion Ratio (FCR)}

Konversi pakan atau FCR dan efesiensi pakan merupakan indikator untuk menentukan efektifitas pakan. Konversi pakan diartikan sebagai kemampuan kultivan (ikan) mengubah pakan menjadi daging, sedangkan efisiensi pakan diartikan sebagai bobot basah dari daging ikan yang diperoleh dalam setiap satuan berat kering dari pakan diberikan kepada ikan dalam hal 


\section{Median Volume IX Nomor 1 Bulan Februari 2017}

ini ikan nila (Watanabe, 1988), Afrianto, dan Liviawaty, (2005).Nilai FCR menunjukan sejauh mana pakan efisien dimanfaatkan ikan peliharaan. Oksigen secara tidak langsung memberikan pengaruh terhadap besar kecilnya konversi pakan (Soetomo, 1987).Nilai dari FCR yang dihasilkan selama penelitian dari tiga perlakuan dilihat pada Gambar 3 berikut.

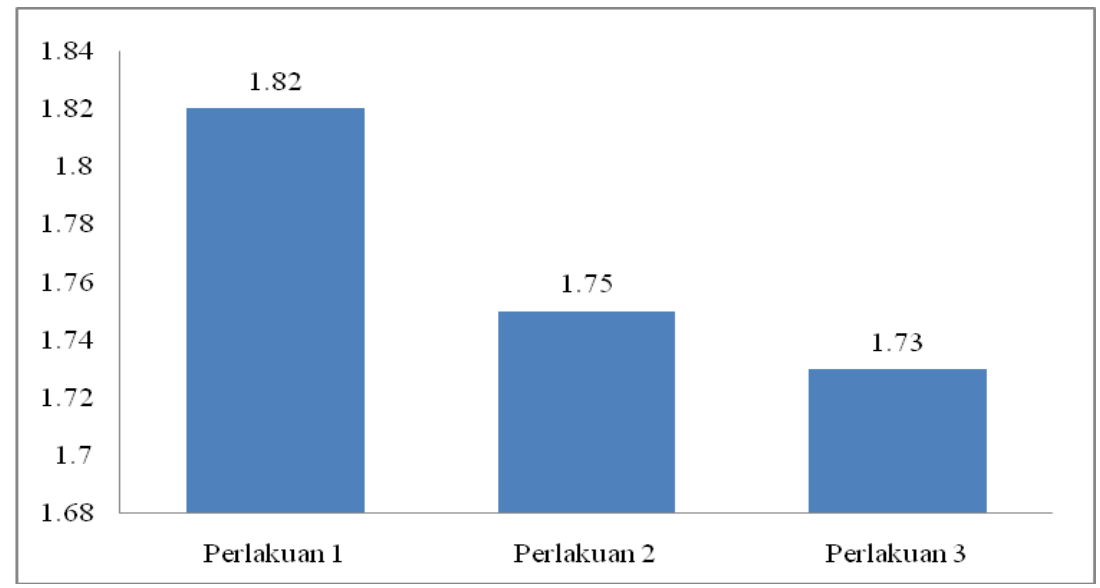

Gambar 3. Grafik Nilai FCR

Gambar 3 di atas menunjukkan bahwa pemberian probiotik pada perlakuan Pertama (I) dengan dosis sebanyak $5 \mathrm{ml}$, hasil yang diperoleh untuk nilai FCR yaitu 1.82, pada perlakuan Kedua (II)pemberian probiotik dengan menggunakan dosis $10 \mathrm{ml}$, nilai FCR yang diperoleh yaitu 1.75 dan pada Perlakuan Ketiga (III) dengan pemberian probiotik menggunakan dosis sebanyak $15 \mathrm{ml}$, nilai FCR yang diperoleh adalah 1.73. Hasil ini menunjukkan bahwa nilai FCR terbaik terjadi pada Perlakuan IIIdengan pemberian dosis probiotik pada pakan sebesar $15 \mathrm{ml}$ diperoleh nilai FCR 1.73. Hal ini menunjukkan bahwa pemberian pakan sebesar $1.73 \mathrm{~kg}$,dihasilkan ikan nila dengan berat $1 \mathrm{~kg}$.

Menurut Putri, dikutip dari BPPP Tegal,dengan menggunakan probiotik,FCR dapat ditekan oleh pembudidaya ikan pada penggunaan pellet atau pakan komersil hingga 0.8 $\mathrm{kg}$ untuk menghasilkan $1 \mathrm{~kg}$ ikan. Selain itu penggunaan probiotik juga bisa mempersingkat waktu pemeliharaan. Hal berbeda diuraikan
Putri, Hasan, dan Haetami, (2012) mengatakan bahwa dengan memberikan probiotik $15 \mathrm{ml}$ pada setiap $1 \mathrm{~kg}$ pakan akan memberikan hasil terbaik terhadap laju pertumbuhan harian sebesar $2,76 \%$ dan FCR sebesar 1,48. Hal ini menunjukan FCR yang efisien sebagaimana dikemukakan oleh (Effendy, 2004), semakin besar nilai FCR, maka semakin banyak pakan yang dibutuhkan untuk memproduksi daging ikan sebanyak $1 \mathrm{~kg}$. Nilai FCR ikan secara umum berkisar 1,5-2,5.

\section{Efisiensi Pemberian Pakan}

Menurut Watanabe (1988) dalam Hasanah (2003), efisiensi pakan adalah hasil dari yang diperoleh dari bobot basah daging ikan dalam setiap satuan berat pellet/pakan kering yang diberikan atau merupakan presentase dari berat ikan yang dihasilkan dibandingkan dengan berat pakan yang diberikan. Hal ini sangat berguna untuk membandingkan nilai pakan yang mendukung pertambahan bobot. Semakin besar ukuran ikan peliharaan makan efisiensi pakan akan semakin 


\section{Median Volume IX Nomor 1 Bulan Februari 2017}

berubah seiring dengan laju pemberian pakan. Efisiensi pakan dipengaruhi beberapa faktor diantaranya kualitas pakan, jumlah pakan, spesies ikan, ukuran ikan dan kualitas air. Adapun nilai efisiensi pemberian pakan yang diperoleh dari penelitian ini disajikan pada Gambar 4 berikut.

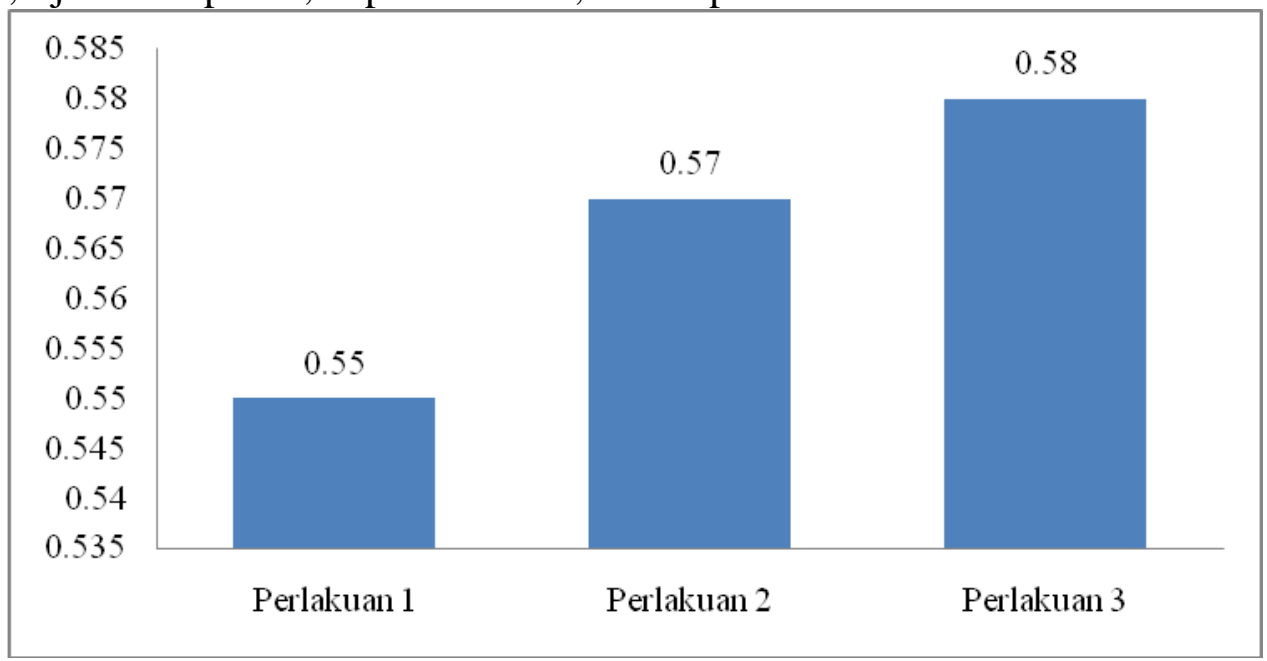

Gambar 4. Grafik Nilai Efisiensi Pakan

Dilihat dari Gambar 4 di atas bahwa pemberian probiotik pada perlakuan Idengan dosis sebesar $5 \mathrm{ml}$ dihasilkan nilai EPP sebesar 55\%, pada pemberian probiotik dengan dosis sebesar10 $\mathrm{ml}$ dihasilkan nilai EPP sebesar $57 \%$ dan pada pemberian probiotik dengan dosis sebesar15 ml dihasilkan nilai EPP sebesar 58\%. Hasil ini menunjukkan bahwa nilai EPP terbaik diperoleh pada perlakuan IIIdengan pemberian dosis probiotik sebesar $15 \mathrm{ml}$, diperoleh nilai EPP yaitu $58 \%$. Dengan ini menunjukkan bahwa dengan pemberian pakan $1 \mathrm{~kg}$ maka akan terkonversi menjadi daging ikan nila sebesar $0.58 \mathrm{~kg}$. Berdasarkan hal tersebut, menunjukkan bahwa nilai efisien pakan yang baik dikaitkan dengan pernyataan Dirjen Perikanan (1985) dalamKoroh, \& Lumenta, (2014)bahwa pakan yang baik disyaratkan mempunyai nilai efisiensi pakan (EP) lebih dari $25 \%$.

\section{Manajemen Kualitas Air}

\section{Suhu}

Suhu mempengaruhi pertumbuhan kultivan serta kelangsungan hidupnya. Hal ini karena suhu berpengaruh terhadap metabolisme, kadar oksigen, dan reaksi kimia dalam perairan.Suhu air mempunyai pengaruh yang besar terhadap proses pertukaran zat atau metabolisme dari makhluk-makhluk hidup. Selain itu juga suhu berpengaruh terhadap kadar oksigen terlarut, dimana semakin tinggi suhu suatu perairan maka semakin cepat pula oksigen dalam air mengalami kejenuhan (Asmawi, 1983) dalam Widyati (2018).Pada penelitian ini, suhu yang diperoleh ditunjukkan pada Gambar 5 dan Gambar 6di bawah ini. 


\section{Median Volume IX Nomor 1 Bulan Februari 2017}

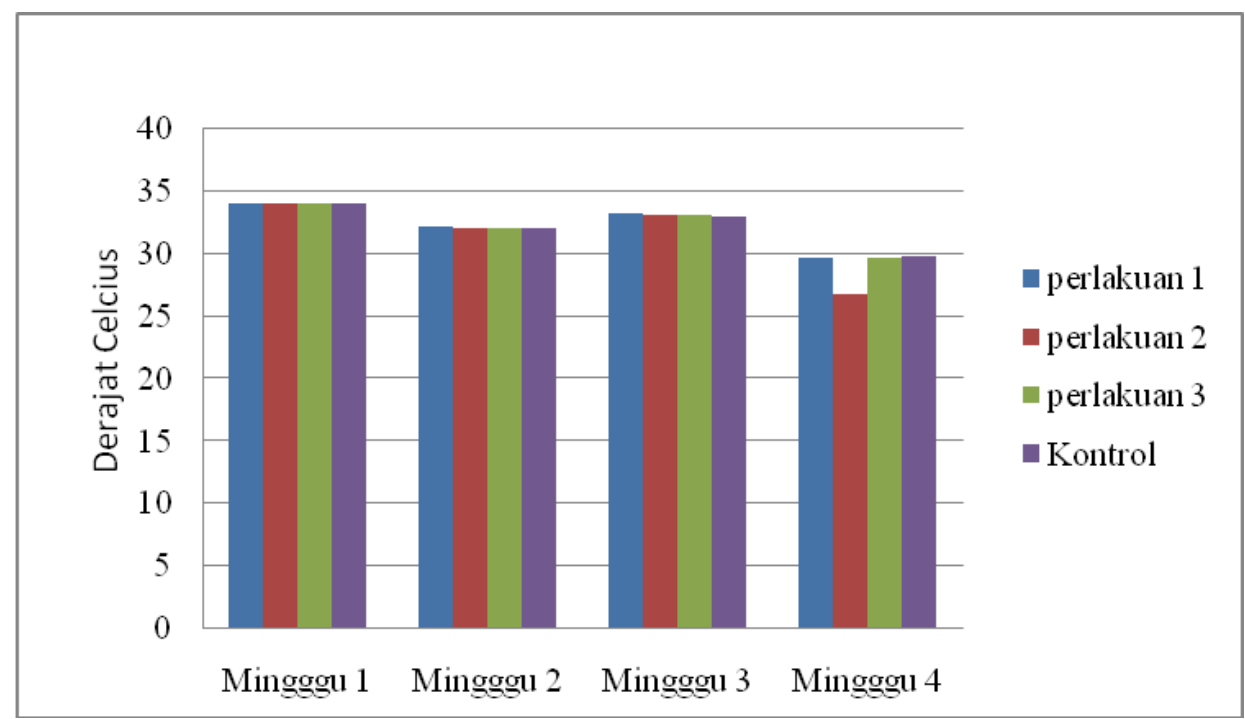

Gambar 5. Grafik Nilai Pengukuran Suhu pada Pagi Hari

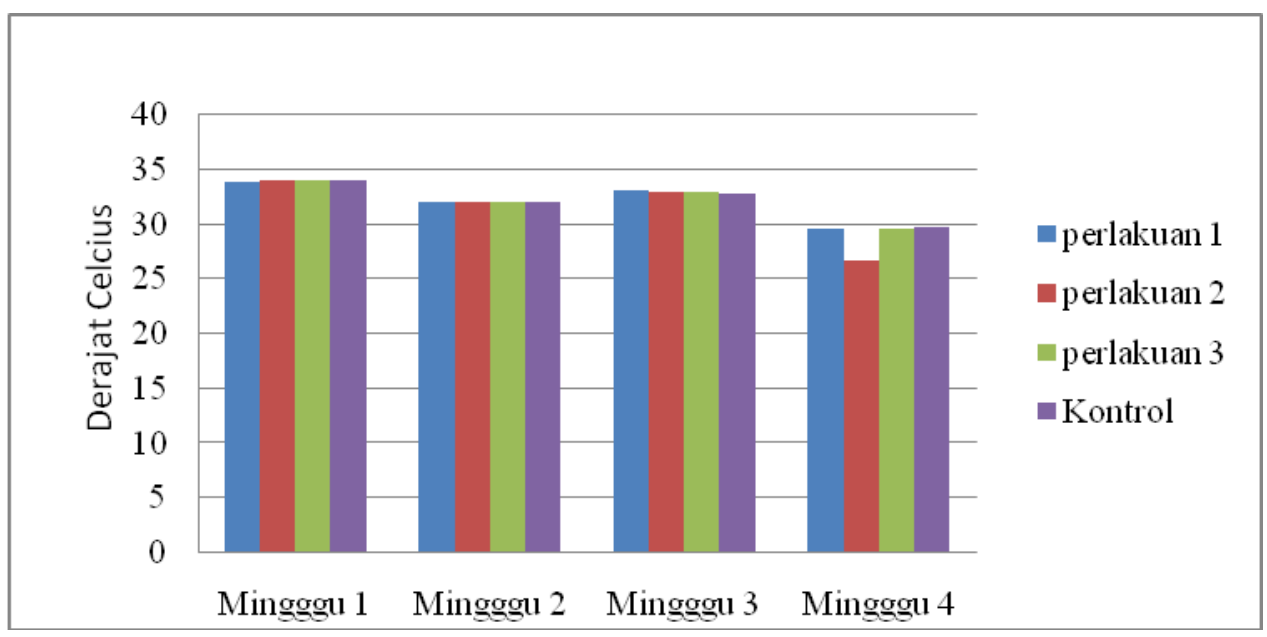

Gambar 6. Grafik Nilai Suhu pada Sore Hari

Gambar 5 dan Gambar 6 di atas menunjukkan bahwa suhu selama penelitian ini berkisar antara $26,9^{0}-34^{\circ} \mathrm{c}$. Suhu tertinggi rata-rata didapatkan pada minggu 1. Perbedaan suhu yang didapatkan yang sering mengalami perubahan karena adanya perbadaan cuaca yang sering terjadi di tempat penelitian.

\section{Derajat Keasaman atau pH}

Derajat keasaman $(\mathrm{pH})$ adalah ukuran konsentrasi ion hydrogen yang menunjukkan suasana asam atau basa suatu perairan. $\mathrm{pH}$ air Faktor dipengaruhi oleh konsentrasi karbondioksida dan senyawa yang bersifat asam. Nilai $\mathrm{pH}$ yang kurang dari 7 menunjukkan lingkungan dengan kondisi masam, nilai $\mathrm{pH}$ di atas 7 menunjukkan lingkungan yang basa (alkalin) sedangkan $\mathrm{pH}$ sama dengan 7 menunjukkan bahwa keadaan lingkungan perairan yang netral (Lesmana, 2004). Nilai pH pada penelitianini, ditampilkan pada Gambar 7 berikut. 


\section{Median Volume IX Nomor 1 Bulan Februari 2017}

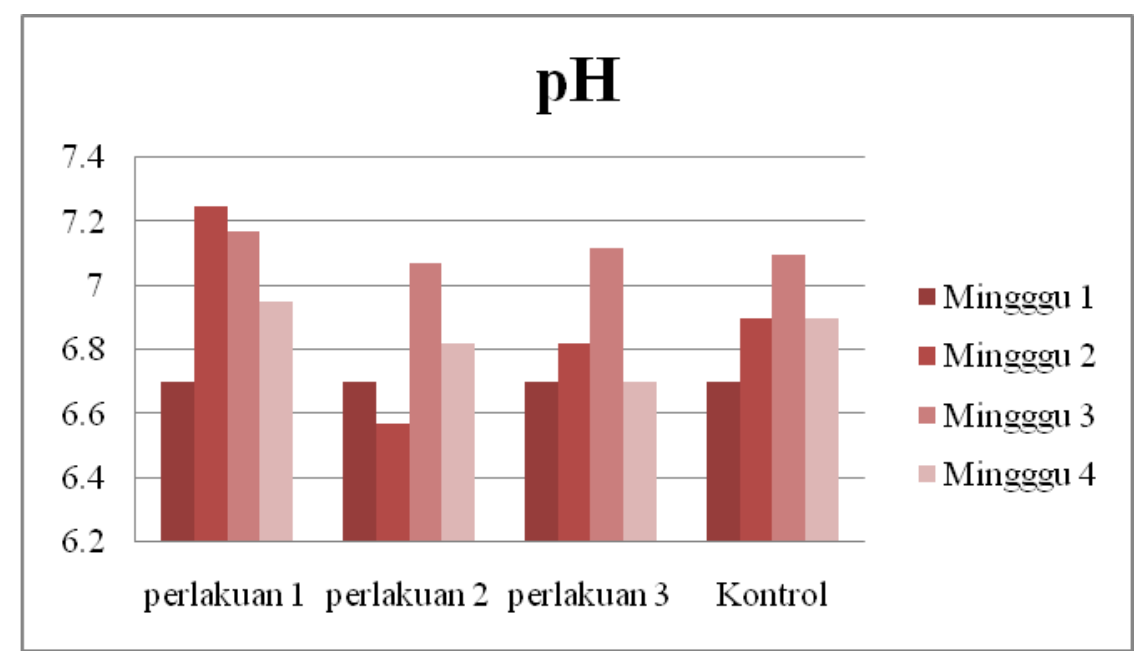

Gambar 7. Grafik Nilai pH Air

Dari Gambar 7 di atas hasil pengukuran selama penelitian bahwa nilai $\mathrm{pH}$ berkisar antara 6.7-7.2. Nilai $\mathrm{pH}$ tertinggi ditunjukkan pada minggu ke dua pada perlakuan pertama sebesar 7.2. Dari hasil pengukuran $\mathrm{pH}$ yang didapatkan dapat dikategorikan sebagai $\mathrm{pH}$ optimal yang baik bagi budidaya ikan utamanya ikan nila. Asmawi (1983) mengatakan bahwa pH minimum yang ditoleransi oleh ikan air tawar pada berkisar antara 4,0 hingga 11,0. Menurut Soeseno (1971), bila kadar $\mathrm{pH}$ secara terus menerus terlalu rendah atau terlalu tinggi, akan menyebabkan terhambatnya pertumbuhan ikan dikarenakan pada suasana tersebut mengganggu pertukaran zat di dalam tubuhnya.

\section{Oksigen Terlarut atau Dissolved Oksigen (DO)}

Dissolved

Oksigen(DO)

merupakan oksigen terlarut dalam perairan yang sangat diperlukan untuk proses respirasi baik plankton maupun ikan. Hasil pengukuran oksigen ditampilkan pada Gambar 8.

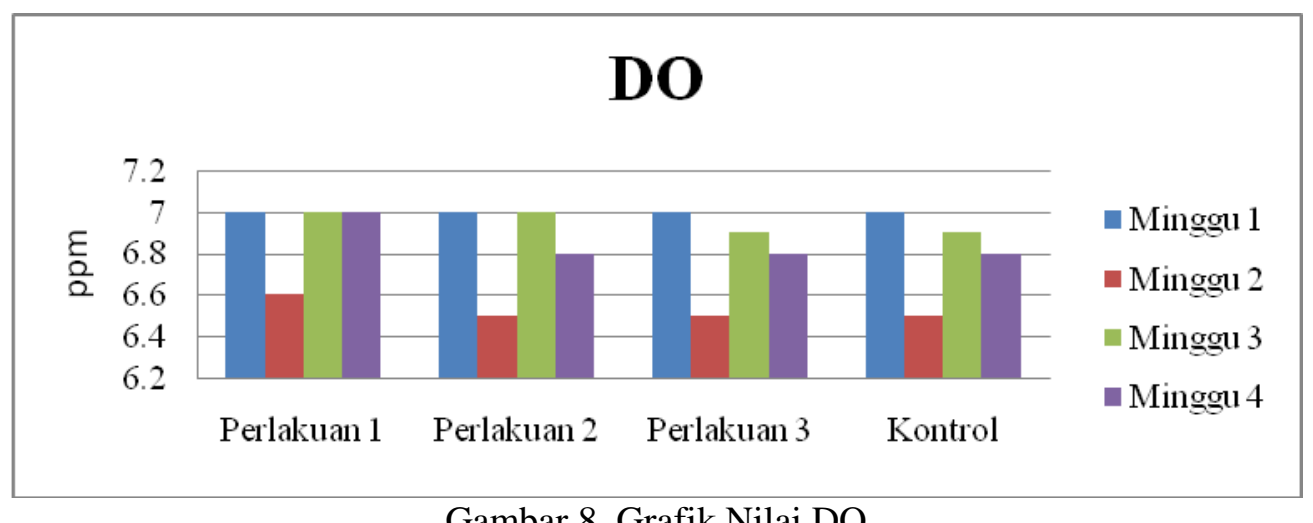

Dari Gambar 8 diatas menunjukkan bahwa hasil pengukuran DO berkisar antara 6.5-7 ppm. DO terendah ditunjukkan pada minggu kedua dengan setiap perlakuan memiliki DO rata-rata 6.5 ppm.Pada minggu 1,3 , dan 4 memiliki rata-rata kadar oksigen yaitu 7 ppm.Dari hasil pengukuran DO yang mengalami perubahan yang terjadi selama penelitian disebabkan beberapa faktor yaitu jika terjadi kekeruhan yang disebabkan oleh sisa sisa makanan dan kotoran ikan dan jika terjadi mati lampu 
sehingga aerator tidak berfungsi untuk variasi perubahan DO yang terjadi dalam hal penelitian ini sangat kecil sehingga tidak menganggu kehidupan ikan. Efendi (2003) mengatakan pengaruh kadar DO bagi kelangsungan hidup ikan diuraikan sebagai berikut:

- $\quad<0.3$ ppm hanya sedikit ikan yang bertahan.

- 0.3-1.0 ppm akan mengakibatkan kematian ikan jika berlangsung terus-menerus.

- 1-5 ppm ikan akan hidup pada kisaran ini, tetapi pertumbuhan ikan menjadi lambat jika berlangsung lama.

- > 5 ppm,pada kisaran ini disukai hampir semua biota akuatik.

\section{SIMPULAN}

Dari hasil penelitian yang dilakukan dapat ditarik kesimpulan bahwa penambahan probiotik menggunakan dosis berbeda yang diberikan pada pakan ikan, tidak memberikan pengaruh signifikan/nyata terhadap pertumbuhan baik berat maupun panjang dari ikan nila merujuk pada hasil uji sidik ragam anova. Pemberian probiotik pada pellet lebih berpengaruh terhadap FCR ikan nila. FCR terbaik merujuk pada penelitian ini terlihat pada perlakuan III dengan nilai FCR yaitu 1.73. Hal ini menunjukan bahwa untuk mendapatkan ikan seberat $1 \mathrm{~kg}$ diperlukan pakan sebanyak 1,73 $\mathrm{kg}$.

\section{DAFTAR PUSTAKA}

Afrianto, I. E., \& Liviawaty, I. E. (2005). Pakan Ikan dan Perkembangannya. Kanisius.

Akhmad, M. (2011). Budidaya Beberapa Vaarietas ikan sepat rawa (Trichogaster trichopterus Pall) dengan pemberian pakan menyuplei oksigen. Namun komersial. Fish Scientiae, 1 (2), 214-217.

Arboleda, C. R. 1981. Communications Ressearch. Manila: CFA. www.eurekapendidikan.com/20

15/11/metode-penelitianeksperimen.html?m=1. Diakses pada tanggal 20 Mei 2016.

Asmawi, S. 1983. Pemelioharan Ikan Dalam Keramba. PT. Gramedia. Jakarta.

www.agustyar.com/2015/04/kim ia-air.html?=1. Diakses pada tanggal 21 Maret 2016.

Dirjen Perikanan. 1985. Spesifikasi Teknik Pakan Udang. Direktorat Jendral Perikanan. Direktorat Bina Produksi. Jakarta 20 Hal.

Djarijah, A. S. 1995. Nila Merah. Pembenihan dan Pembesaran Secara Intensif. Kanisius. Yogyakarta.

Effendi,I. 2004. Pengantar akuakultur. Jakarta: penebar swadaya.

(FAO Fisheries and Aquaculture Department, -).

Hanafiah, K. A. (1991). Rancangan percobaan: Teori \& aplikasi. Rajawali Pers.

Khairuman, A., \& Amri, K. (2005). Budi Daya Ikan Nila Secara Intensif. AgroMedia.

Koroh, P. A., \& Lumenta, C. (2014). Pakan suspensi daging kekerangan bagi pertumbuhan benih sidat (Anguilla bicolor). $e$ Journal BUDIDAYA PERAIRAN, 2(1).

Lesmana, D.S. 2004. Kualitas Air Untuk Ikan Hias Air Tawar. Penebar Swadaya Jakarta.

Mursalim, I., Mustami, M. K., \& Ali, A. (2018). Pengaruh Penggunaan Pupuk Organik Mikroorganisme Lokal Media Nasi, Batang Pisang, Dan Ikan Tongkol Terhadap Pertumbuhan 


\section{Median Volume IX Nomor 1 Bulan Februari 2017}

Tanaman Sawi (Brassica juncea). Jurnal Biotek, 6(1), 3242.

Putri, F. S., Hasan, Z., \& Haetami, K. (2012). Pengaruh Pemberian Bakteri Probiotik Pada Pelet Yang Mengandung Kaliandra (calliandracalothyrsus) Terhadap Pertumbuhan Benihikan Nila (Oreochromis Niloticus). Jurnal Perikanan Kelautan, 3(4).

Putri, R. (tanpa tahun). Efisiensi Pakan Dengan Fermentasi Pada Sistem Bioflok. (Widyaiswara BPPP
Tegal). Dikutip dari http://www.bppptegal.com/web/index.php/artikel 1378-efisiensi-pakan-denganfermentasi-pada-sistembioflok.Pada tanggal 15/01/2017; pukul 22:49 WIT. Setyanto, A. E. (2013). Memperkenalkan kembali metode eksperimen dalam kajian komunikasi. Jurnal ilmu komunikasi, 3(1). 